\title{
BLOOD PLASMA PROGESTERONE LEVELS DO NOT CORRELATE WITH LITTER SIZE IN THE AMERICAN MINK (Neovison vison)
}

\section{ZALEŻNOŚĆ POMIEEDZY STĘŻENIEM PROGESTERONU W SUROWICY KRWI SAMIC NOREK AMERYKAŃSKICH (Neovison vison) A LICZBA URODZONYCH SZCZENIĄT W MIOCIE}

\author{
Department of Biotechnology of Animal Reproduction and Environmental Hygiene, \\ West Pomeranian University of Technology, Szczecin, Poland \\ ${ }^{1}$ Laboratory of Animal Anatomy Faculty of Biotechnology and Animal Breeding, \\ West Pomeranian University of Technology, Szczecin, Poland
}

\begin{abstract}
Streszczenie. Celem pracy było określenie, czy istnieje związek pomiędzy stężeniem progesteronu, oznaczanego w wybranym okresie ciąży, a liczbą urodzonych szczeniąt w miocie. Doświadczenie przeprowadzono na fermie norek zlokalizowanej w zachodniej Polsce. Materiał do badań stanowiła krew pobrana od jednorocznych samic odmiany barwnej biała Hedlunda (WH). Próby do analiz pozyskano w dwóch terminach od reprezentatywnej grupy 30 samic. Pierwszy raz krew pobrano 22 lutego, czyli przed okresem kojarzeń; powtórne pobranie nastapiło 12 kwietnia w okresie ciąży samic, na około trzy tygodnie przed porodem. Analiza uzyskanych wyników, dotyczących stężenia progesteronu w surowicy krwi samic norek, wskazuje na znaczne zróżnicowanie osobnicze w obrębie analizowanej grupy zwierząt. Współzależność pomiędzy stężeniem progesteronu w surowicy krwi samic norek a liczbą urodzonych przez nie szczeniąt nie wykazała korelacji.
\end{abstract}

Key words: American mink, progesterone, reproduction.

Słowa kluczowe: norka amerykańska, progesteron, rozmnażanie.

\section{INTRODUCTION}

The mink belongs to animals with a complex physiology of reproduction. As most Mustelidae species, American mink attains sexual maturity within the first year of life, at age about 10 months (Basu et al. 2007; Felska-Błaszczyk et al. 2010; Piórkowska and Kowalska 2014). Sexual maturation signs involve permanent morphological and hormonal changes in the reproductive system, as expressed with maturation of the ovarian follicles (folliculogenesis), ovulation, luteinization and luteolysis of the corpus luteum, which is reflected in regular oestrus cycles (Szeleszczuk 2001). In the Northern Hemisphere, the breeding season in mink is relatively short-spanned, and the onset of heat is strictly associated with

Corresponding author - Adres do korespondencji: Beata Seremak, Department of Biotechnology of Animal Reproduction and Environmental Hygiene, West Pomeranian University of Technology, Szczecin, Klemensa Janickiego 29, 71-270 Szczecin, Poland, e-mail: beata.seremak@zut.edu.pl 
gradually lengthening daylight (Travis and Pilbeam 1980). Heat is initiated by the 10-hour daylight (when the day is approx. 2 hours longer that the 8-hour winter light phase of the day) (Klotchkov et al. 1998; Felska-Błaszczyk et al. 2010). As a result of the gradually growing light stimulus, the hypothalamus releases gonadoliberin ( $\mathrm{FSH} / \mathrm{LH}-\mathrm{RH})$, a neurohormone that stimulates the anterior pituitary gland to secrete follicle-stimulating hormone (FSH), which triggers an intense growth of the ovarian follicles (Bieguszewski 1984). The breeding season may last from 2-3 weeks (Trani et al. 2007) to one month (Klotchkov and Eryuchenkov 2003); ovarian follicles maturate during this period. The discrepancy between estrus length estimations are due to the lack of visible heat symptoms in female mink. Moreover, according to Szeleszczuk(2001), Ślaska et al. (2009) and Felska-Błaszczyk et al. (2010), the heat onset date may vary depending on the color variety of farmed mink.

Mink reproduction is also characteristic for a varied gestation length, which heavily depends on the date of mating (Seremak et al. 2009), which is due to the diapause preceeding gestation proper. After diapause, the embryos resume their growth and implantation takes place. Diapause duration is regulated by external and internal factors affecting the system, whereas the end of this period is defined by Lopes et al. (2004) as the resumption of embryonic mitotic activity regulated by species-specific factors.

External, environmental regulating factors include photoperiod, temperature, and metabolic stress. Photoperiod is crucial for the completion of diapause, as it induces emryonic implantation in the uterus. Plasma progesterone begins to grow about 40 days before parturition, with its peak observed in early April (Pilbeam et al. 1979), i.e. 10-25 days post implantation. Amstislavsky et al. (2009) found the maximum fecal progesterone level in female mink on the 12th day after mating. Pilbeam et al. (1979) report that the level of progesterone drops as gestation goes by to a low level on the moment of parturition.

The aim of this paper was to find whether there is a relationship between progesterone levels in selected periods of gestation and litter size at birth.

\section{MATERIAL AND METHODS}

The observations took place on a mink farm located in Northern Poland. The animals were housed in open shades and fed standard feed according to nutritional requirement of the species. The mink received semi-liquid feed based on chicken and fish, served directly on the cages with an automatic dispenser.

The material involved blood samples drawn from 30 White Hedlund (WH) females aged 1 year. Samplings took place twice, on 22 February, which was before matings, and again on 12 April, when the femals were pregnant.

Blood was collected from a claw of a front or a real leg, according to the common procedure applied to this species (Laboratory services, Nova Scotia, Departament of Agriculture, Quality Evaluation Division 2007) (Fletch and Wobeser 1970; Mañas et al. 2001). Samplings were performed from 9 a.m. to 11 a.m. (Tauson et al. 2000), and the samples was centrifuged, and the resulting plasma was stored frozen at $-26^{\circ} \mathrm{C}$ until analysis. Hormone quantitative measurements were carried out by immunofluorescent method, using Delfia microplate assays produced by Perkin-ElmerWallacOy (Finland). 
The data analysis was performed using the Statistica $12 \mathrm{PL}$ package. Correlation between the progesterone blood concentration in female mink and the litter size was determined by Spearman's rank correlation coefficient.

\section{RESULTS}

Figure 1 presents data on blood plasma progesterone in females preparing to the breeding season (blood sampled on 22 February). The results varied by specimen and the lowest recorded hormone level was $0.17 \mathrm{ng} / \mathrm{ml}$, while the highest was $1.58 \mathrm{ng} / \mathrm{ml}$ (Fig. 1). A majority of results (20 samples) ranged from 0.2 to $0.5 \mathrm{ng} / \mathrm{ml}$.

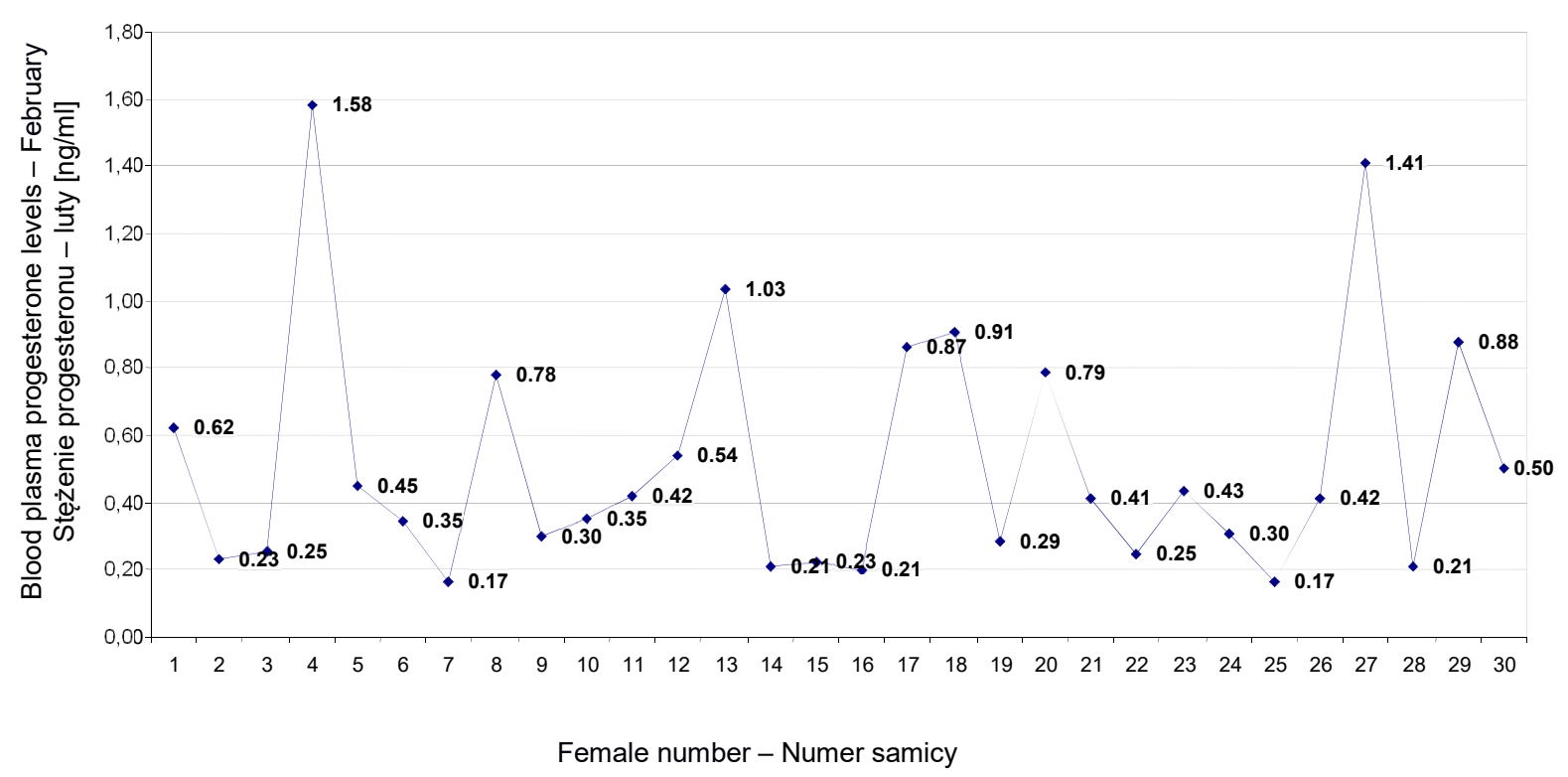

Fig. 1. Blood plasma concentration of progesterone in female mink preparing for breeding season (blood drawn on February 22)

Ryc. 1. Stężenie progesteronu w surowicy krwi pobranej od samic norek w okresie przygotowania do rozrodu (data pobrania krwi: 22 lutego)

Analysis of blood collected from pregnant females (12 April) showed a considerable (Fig. 2) increase in progesterone concentration, which ranged from 11.54 to $66.99 \mathrm{ng} / \mathrm{ml}$. Progesterone levels in individual females were compared with their litter size. Consequently, the lowest levels of progesterone were reported for females which gave birth to 5 and 7 kits (females number 6 and 14), while the highest concentration was recorded for the female number 3 , which gave birth to 3 kits. There was no correlation between the concentration of progesterone in female mink and the number of kits born by them - the correlation coefficient proved statistically non-significant. 


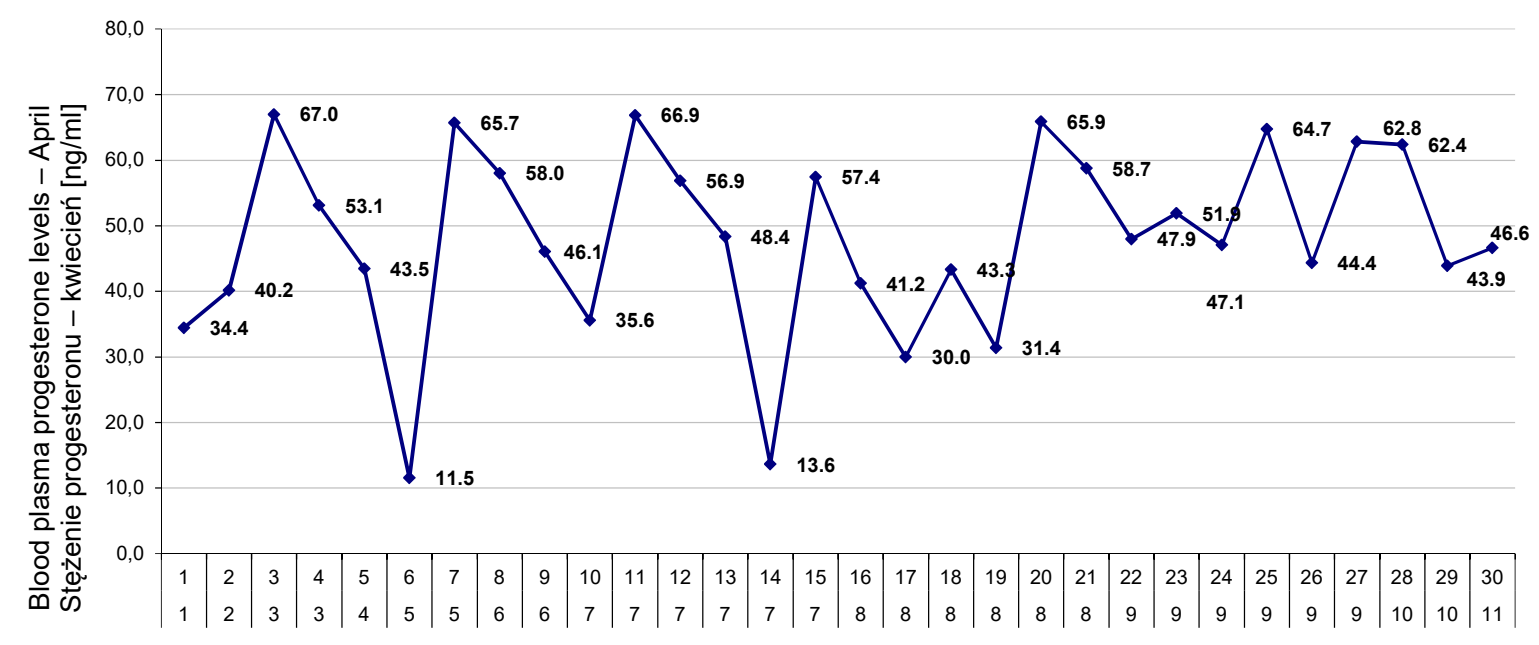

Female number - Numer samicy

Litter size - Liczba urodzonych młodych

Fig. 2. Blood plasma concentration of progesterone in pregnant mink in relation to litter size at birth (blood drawn on April 12)

Rys. 2. Stężenie progesteronu w surowicy krwi pobranej od ciężarnych samic norek w zależności od liczby urodzonych szczeniąt (data pobrania krwi: 12 kwietnia)

\section{DISCUSSION}

In order to depict changes in the hormonal status of pregnant mink, we measured their blood plasma concentration of progesterone. Analysis of the results showed ample fluctuations indicating individual variability of this parameter. The lowest recorded level of the hormone before the mating season was at $0.17 \mathrm{ng} / \mathrm{ml}$, while the highest $1.58 \mathrm{ng} / \mathrm{ml}$. These values differed from the data obtained by Dziadosz et al. (2015), who measured the level of progesterone in blood collected on February 18 from females of two color varieties (Pearl and Black Standard), report the levels ranging from 0.4-0.8 ng/ml. According to Martinet et al. (1983), progesterone secretion can be reduced or even completely stopped at a daylight shorter than 12 hours, i.e. at the end of February. A short photoperiod affects the secretion of melatonin, whose increasing concentration suppresses the release of gonadotropic hormones from the hypothalamus (Bishnupuri and Heldar 2000), as well as progesterone and estradiol (Martinet et al. 1983). Similarly, Ravault et al. (1986) found that a short daylight blocking the secretion of prolactin in pregnant and non-pregnant mink and in consequence leads to inhibition of progesterone secretion.

On the other hand, when analyzing the concentration of progesterone in blood collected from pregnant females (12 April), a considerable increase in the range from 11.54 to $66.99 \mathrm{ng} / \mathrm{ml}$, as compared with the first sampling, was demonstrated. According to numerous authors, e.g. Berria et al. (1989), Kaplan et al. (1991), Amstislavsky et al. (2000) and Persson(2007), a progressingly increasing daylight phase in spring causes the increase of prolactin secretion, which activates the corpus luteum to produce progesterone, which in turn leads to implantation of the embryo. The level of progesterone increases about 40 days before 
parturition and its peak concentration is observed early April, that is before and during embryo implantation (Møller 1973; Persson 2007). In contrast, Stoufflet et al. (1989) claim that the highest concentration of plasma progesterone in pregnant mink occurs 20 days before parturition, and thus a few days after implantation of the embryo. According to Møller(1973) and Allais and Martinet (1978), the peak values of progesterone in the blood of female American mink remain in the range 72 to $160 \mathrm{ng} / \mathrm{ml}$; after reaching its maximum, the level gradually decrease until birth (Sundquvist et al. 1989; Persson 2007). The values obtained in this experiment did not differ from those presented by Felska-Błaszczyk et al. (2012). These authors, who measured plasma progesterone in blood collected from mink females of two color varieties (Black Standard and Brown Standard) on 8 April, recorded the average progesterone level of 57.59 and $59.56 \mathrm{ng} / \mathrm{ml}$ for each color, respectively.

The level of progesterone concentration for individual females was compared with the number of kits born by them in the litter. The lowest levels of progesterone in pregnant females were reported for those who gave birth to 5 and 7 pups (females numbers 6 and 14), while the highest concentration was recorded for the female number 3 , which gave birth to 3 offspring. There was no correlation between the concentration of plasma progesterone of female minks and the litter size.

\section{CONCLUSION}

Analysis of the results on the concentration of plasma progesterone in female mink revealed an enormous individual variability within the analyzed group of animals. There is no correlation, however, between progesterone concentration in female mink and the litter size at birth.

\section{REFERENCES}

Allais C., Martinet L. 1978. Relation between daylight ratio, plasma progesterone levels and timing of nidation in mink (Mustela vison). J. Reprod. Fert., 54, 133-136.

Amstislavsky S., Lindeberg H., Jarvinen M., Kizilova H., Zudova G., Ternovskaya Yu. Valtonen M. 2000. Ex-situ preservation of Mustelidae : primer if a application of genetic resource bank concept with the use of polecats as the model species. Scientific 24(1), 45-58.

Amstislavsky S. 2000. Reproductive biology and embryo technology in Mustelidae. Kuopio Univ. Publ. C. Nat. Environ. Sci. 256, 1-149.

Basu N., Scheuhammer A.M., Bursian S.J., Elliot J., Rouvinen-Wantt K., Man Chan H. 2007. Mink as a sentinel species in environmental health. Environ. Res. 103, 130-144.

Bieguszewski H. 1984. Hormonalna regulacja cyklu płciowego samic [Hormonal regulation of the female sex cycle]. Hod. Drob. Inwent. 12, 8-9. [in Polish]

Berria M., Joseph M.M., Mead R.A.1989. Role of prolactin and luteinizing hormone in regulating timing of implantation in the spotted skunk. Biol. Reprod. 40, 232-238.

Bishnupuri K. S., Haldar C. 2000. Profile of organ weights and plasma concentrations of melatonin, estradiol and progesterone during gestation and post-parturition periods in female indian palm squirrel Funambuluspennanti. Indian J. Exp. Biol. 38(10), 974-81.

Felska-Błaszczyk L., Lasota B., Seremak B., Zielińska-Zygmunt N. 2011. Plasma concentrations of progesteroneand testosterone in pregnantmink (Neovison vison) depend on fur-color varietyof the female. Acta Sci. Pol., Zootechnica 11(3), 11-20. 
Felska-Błaszczyk L., Sulik M., Dobosz M. 2010. Wpływ wieku i odmiany barwnej na wskaźniki rozrodu norek (Neovison vison) [Effect of mink (Neovison vison) reproduction in relation to age and colour variety]. Acta Sci. Pol., Zootechnica 9(3), 19-30.

Fletch S.M., Wobeser G. 1970. A technique for safe multiple bleedings, or intravenous injections in mink. Can. Vet. J. 11(2), 33-33.

Dziadosz-Styś M.,Seremak B., Felska-Blaszczyk L., Lasota B. 2015. Progesterone profile in the sexual cycle of female American mink (Neovison vison). Acta Sci. Pol., Zootechnica 14(2), 85-92.

Kaplan J.B., Berria M., Mead R.A. 1991. Prolactin levels in the western spotted skunk: changes during pre- and periimplantation and effect of melatonin and lesions to the anterior Hypothalamus. Biol. Reprod. 44, 991-997.

Klotchkov D.V., Eryuchenkov P.A. 2003. Effects of hCG on Folliculogenesis and fecundity in mink (Mustela vison Scherb). Theriogenology 60, 1583-1593.

Klotchkov D.V., Trapezov O.V., Kharlamova A.V. 1998. Folliculogenesis, onset of puberty and fecundity of Mink (Mustela vison Scherb) selectively bred for docility or aggressiveness. Theriogenology 49, 1545-1553.

Lopes F.L., Desmarais J.A., Murphy B.D. 2004. Embryonic diapause and its regulation. Reproduction 128, 669-678.

Martinet L., Allaind D., Meunier M. 1983. Regulation in pregnant mink (Mustela vison) of plasma progesterone and prolactin concentrations and regulation of onset ofthe spring moult by day light and melatonin injections, Can J. Zool. 61, 1959-1963.

Mañas S., Ceña J.C., Ruiz-Olmo J., Palazón S., Domingo M., Wolfinbarger J.B., Bloom M.E. 2001. Aleutian mink disease parvovirus in wild riparian carnivores in Spain. J. Wildl. Dis. 37, 138-144.

Møller O.M. 1973. Plasma progesterone before and after ovariectomy in unmated and pregnant mink, Mustela vison. J. Reprod. Fert. 37, 367-372.

Persson S. 2007. The Mink (Mustela vison) as an indicator of environmental reproductive toxicity. Swed. Univ. Agric. Sci. 50, 1-23.

Pilbeam T.E., Concannon P.W., Travis H.F. 1979. The annual reproductive cycle of mink (Mustela vison). J. Anim. Sci. 48, 578-584.

Piórkowska M., Kowalska D. 2014. Charakterystyka populacji hodowlanych i dziko żyjących norek amerykańskich [Characteristics of farmed and wild populations of American mink]. Wiad. Zootech. 52(2), 122-129. [in Polish]

Ravault J.P., Martinet L., Bonneford C, Claústrate, Brun J. 1986. Diurnal variations of plasma melatonin concentrations. J. Pineal Res. 3, 365-373.

Seremak B., Lasota B., Masłowska A., Dziadosz M., Mieleńczuk G. 2009. Analiza zależności między datą pierwszego krycia a datą implantacji i długością ciąży u norki amerykąńskiej (Neovison vison) odmiany Wild i Standard [Analysis of relation between the date of first mating to the date of implantation and gestation length in wild and standard color american mink (Neovison vison)]. Acta Sci. Pol., Zootechnica 8(4), 41-48. [in Polish]

Stoufflet I., Mondain-Monval M., Simon P., Martinet L. 1989. Patterns of plasma progesterone, androgen and oestrogen concentrations and in-vitro ovarian steroidogenesis during embryonic diapause and implantation in the mink (Mustela vison). J. Reprod. Fertil. 87, 209-221.

Sundquvist C., Amador A.G., Bartke A. 1989. Reproduction and fertility in the mink (Mustela vison). Reprod. Fen. 85, 413-441.

Szeleszczuk O. 2001. Czynniki wpływające na wyniki rozrodu i odchowu mięsożernych zwierząt futerkowych [Factors affecting the results of breeding and rearing of carnivorous fur Animals]. Prz. Hod. 11, 21-23. [in Polish]

Ślaska B., Rozempolska-Rucińska I., Jeżewska-Witkowska G. 2009. Variation in some reproductive traits of mink (Neovison vison) according to their coat colour. Ann. Anim. Sci. 9(3), 287-297.

Tauson A.H., Fink R., Forsberg M., Lagerkvist G., Wamberg S. 2000. LH release in mink (Mustela vison). Pattern of the LH surge and effect of metabolic status. Reprod. Nutr. Dev. 40, 229-247. 
Trani M.K., Ford W.M., Chapman B.R. 2007. The land manager's guide to mammals of the South. The Nature Conservancy, Southeastern Region, Durham, North Carolina, USA.

Travis H.F., Pilbeam T.E. 1980. Use of artificial light and day length to alter the life cycles of mink. J. Anim. Sci. 50, 1108-1112.

Abstract. The aim of the study was to test whether there is a relationship between the plasma concentration of progesterone in a given stage of pregnancy and the litter size at birth. The study was carried out on a mink farm located in western Poland. Blood samples for analyses were drawn from year-old White Hedlund $(\mathrm{WH})$ females. Samples were collected from 30 females, first on 22 February, i.e. before the mating season, and on 12 April, from pregnant females, about 3 weeks before expected parturitions. Plasma progesterone levels revealed a high individual variability within the studied group of mink. No significant correlation was found between blood plasma progesterone in pregant females and the average litters size at birth. 
